\title{
PENGARUH CURRENT RATIO, DEBT TO EQUITY RATIO, DAN INVENTORY TURN OVER TERHADAP RETURN ON ASSET PADA PERUSAHAAN SEKTOR PROPERTY DAN REAL ESTATE YANG TERDAFTAR DI BURSA EFEK INDONESIA TAHUN 2014-2018
}

\author{
Abd. Wahid Rizki Sahputra ${ }^{1}$, Endalit Ramayana ${ }^{2}$ \\ Ivonia Florensia ${ }^{3}$,Siska Ika Sartika ${ }^{4,}$ Januardin $^{5}$ \\ Fakultas Ekonomi, Universitas Prima Indonesia \\ rizkisahputra97@gmail.com ${ }^{1}$, endalitramayana@gmail.com ${ }^{2}$, \\ ivoniaflorensia@gmail.com ${ }^{3}$, siskaika2206@gmail.com ${ }^{4}$, januardin@unpri.ac.id ${ }^{5}$
}

\begin{abstract}
Based on the analysis of financial statements on the property and real estate sector listed on the Indonesia Stock Exchange, a phenomenon can be identified at PT. Bekasi Fajar Industrial Estate Tbk current assets increased in 2014-2015 but net income decreased. PT. Alam Sumatera Reality Tbk The total debt in 2017-2018 has decreased but the net profit has decreased. And at PT. Jababeka Industrial Estate Tbk. Inventory in 2016-2017 has increased but net profit has decreased. Based on this phenomenon is not in accordance with the prevailing theory. The population in this study were 27 companies with a purposive sampling method. The analytical method used is multiple regression analysis. The results of this study indicate that CR, DER and ITO partially influence ROA. And simultaneously shows that CR, DER and ITO influence ROA.
\end{abstract}

Keywords: current ratio, debt to equity ratio and inventory turn over, return on asset

\section{PENDAHULUAN}

\section{I.1. Latar belakang}

Sektor property dan real estate adalah salah satu sektor penting di suatu negara dimana sektor ini memiliki resiko saham yang cepat berubah dan resiko yang tinggi. Naiknya harga property dikarenan harga tanah yang cenderung naik dan kebutuhan lahan tanah yang dibutuhkan selalu bertambah seiring dengan berkembangnya jumlah penduduk dan kebutuhan manusia seperti tempat tinggal, gedung perkantoran, pusat perbelanja dan lain-lain.

Profitabilitas memiliki peran penting bagi perusahaan dikarenakan sebagai salah satu dasar menilai kondisi perusahaan bagi kelangsungan hidup dan perkembangan perusahaan. Return on asset adalah rasio yang menjelaskan tingkat keuntungan yang didapat berdasarkan aktiva perusahaan yang dimiliki. Jika semakin meningkatnya Return on asset, maka semakin baik pula kinerja perusahaan .

Current Ratio adalah perbandingan antara aktiva lancar dengan hutang lancar (hutang jangka pendek) .Perusahaan yang mengelola rasio lancarnya dengan baik maka akan menunjukkan bahwa aktiva lancar perusahaan tersebut memiliki likuiditas yang baik.

Debt to equity ratio mengambarkan sejauh mana para pemodal dapat menutupi berbagai utang kepada pihak luar, jika suatu perusahaan tidak bisa mengatur dan mengelola 
dana yang dihasilkan dengan baik secara produktif dari hutang suatu perusahaan itu sendiri, hal tersebut dapat memberikan pengaruh buruk dan memberi dampak terhadap turunnya profitabilitas perusahaan.

Inventory turn over merupakan berputarnya rasio persediaan. Rasio efisiensi yang menujukkan seberapa efektif persediaan dikelola yang membandingkan setiap pokok harga penjualan dengan persediaan rata-rata periode. Penelitian ini bersumber dari Bursa Efek Indonesia Periode 2014-2018 dan dapat dilihat pada tabel 1 berikut:

Tabel 1 Aset Lancar, Penjualan,Persediaan dan laba bersih perusahaan Property dan Real Estate yang Terdaftar di Bursa Efek Indonesia Tahun 2014-2018

(Dalam Jutaan Rupiah)

\begin{tabular}{|l|c|c|c|c|c|}
\hline Perusahaan & Tahun & Aset lancar & Total Utang & Persediaan & Laba bersih \\
\hline \multirow{4}{*}{$\begin{array}{l}\text { PT Bekasi Fajar } \\
\text { Industrial Estate }\end{array}$} & 2014 & 1.248 .542 & 803.492 & 2.493 .180 & 391.352 \\
\cline { 2 - 6 } & 2015 & 1.508 .625 & 1.589 .160 & 3.102 .750 & 211.935 \\
\cline { 2 - 6 } & 2016 & 1.848 .611 & 1.814 .537 & 3.583 .455 & 336.287 \\
\cline { 2 - 6 } & 2017 & 2.044 .717 & 1.870 .815 & 4.167 .144 & 483.387 \\
\cline { 2 - 6 } & 2018 & 2.755 .020 & 2.118 .132 & 4.278 .600 & 422.536 \\
\hline \multirow{4}{*}{$\begin{array}{l}\text { PT Alam } \\
\text { Tbk }\end{array}$} & 2014 & 3.188 .091 & 10.553 .173 & 3.751 .482 & 1.176 .955 \\
\cline { 2 - 6 } & 2015 & 2.698 .917 & 12.107 .460 & 5.550 .193 & 684.287 \\
\cline { 2 - 6 } & 2016 & 3.082 .309 & 12.998 .285 & 5.990 .358 & 510.243 \\
\cline { 2 - 6 } & 2017 & 2.317 .958 & 12.155 .738 & 5.502 .424 & 1.385 .189 \\
\cline { 2 - 6 } $\begin{array}{l}\text { PT Kawasan } \\
\text { Industrial }\end{array}$ Jababeka Tbk & 2018 & 1.449 .848 & 11.339 .568 & 5.314 .516 & 370.586 \\
\cline { 2 - 6 } & 2014 & 5.152 .157 & 3.843 .434 & 660.287 & 394.055 \\
\cline { 2 - 6 } & 2015 & 6.645 .564 & 4.762 .940 & 687.997 & 426.542 \\
\cline { 2 - 6 } & 2017 & 7.458 .654 & 5.095 .107 & 1.008 .624 & 149.840 \\
\hline
\end{tabular}

$\underline{\text { Sumber:www.idx.co.id }}$

PT. Bekasi Fajar Industrial Estate Tbk, yaitu aset lancar ditahun 2014-2015 mengalami penigkatan Rp.1.248.542 menjadi 1.508.625 tetapi laba bersihnya mengalami penurunan dari Rp.391.352 menjadi Rp.211.935,dimana menurut teori seharusnya jika aset lancar naik maka laba bersih seharusnya naik.

PT. Alam Sumatera Reality Tbk, yaitu total hutang ditahun 2017-2018 mengalami penurunan dari Rp.12.155.738 menjadi Rp.11.339.568 tetapi laba bersihnya mengalami penurunan dari Rp.1.385.189 menjadi Rp.970.586, dimana menurut teori seharusnya jika total hutang turun maka laba bersih naik.

PT. Kawasan Industrial Jababeka Tbk, yaitu persediaan di tahun 2016-2017 mengalami peningkatan dari Rp1.008.624 menjadi Rp.1.101.759 tetapi laba bersihnya mengalami penurunan dari Rp.426.542 menjadi Rp.149.840, dimana menurut teori seharusnya jika persediaan naik maka laba bersihnya seharusnya naik. Berdasarkan uraian diatas, maka peneliti tertarik untuk melakukan penelitian yang berjudul PENGARUH CURRENT RATIO, DEBT TO EQUITY RATIO DAN INVENTORY TURN OVER TERHADAP RETURN ON ASSETS PADA PERUSAHAAN SEKTOR PROPERTY DAN REAL ESTATE YANG TERDAFTAR DI BURSA EFEK INDONESIA.

\section{I.2 Indentifikasi Masalah}

Berdasarkan latar belakang masalah diatas, maka identifikasi masalah dalam penelitian ini adalah :

1. Kenaikan Current Ratio tidak selalu diikuti dengan kenaikan Return On Asset pada perusahaan property dan real estate yang terdaftar di Bursa Efek Indonesia pada tahun 
2014-2018.

2. Turunnya Debt to Equity Ratio tidak selalu diikuti dengan kenaikan Return On Asset pada perusahaan property dan real estate yang terdaftar di Bursa Efek Indonesia pada tahun 2014-2018.

3. Kenaikan Inventory Turnover tidak selalu diikuti dengan kenaikan Return On Asset pada perusahaan property dan real estate yang terdaftar di Bursa Efek Indonesia pada tahun 2014-2018.

4. Kenaikan Current Ratio, penurunan Debt to Equity Ratio,dan kenaikan Inventory Turn Over tidak selalu diikuti dengan kenaikan Return On Asset pada perusahaan property dan real estate yang terdaftar di Bursa Efek Indonesia pada tahun 2014-2018.

\section{I.3 Rumusan Masalah}

Berdasarkan identifikasi masalah diatas, maka perumusan masalah dalam penelitian ini adalah:

1. Apakah Current Ratio berpengaruh secara parsial terhadap Return On Asset pada perusahaan sektor property dan real estate yang tercatat di Bursa Efek Indonesia pada tahun 2014-2018?

2. Apakah Debt to Equity Ratio berpengaruh secara parsial terhadap Return On Asset pada perusahaan sektor property dan real estate yang tercatat di Bursa Efek Indonesia pada tahun 2014-2018?

3. Apakah Inventory Turnover berpengaruh secara parsial terhadap Return on Asset pada perusahaan sektor property dan real estate yang tercatat di Bursa Efek Indonesia pada tahun 2014-2018?

4. Apakah Current Ratio, Debt to Equity Ratio, Inventory Turnover berpengaruh secara simultan terhadap Return On Asset pada perusahaan sektor property dan real estate yang tercatat di Bursa Efek Indonesia pada tahun 2014-2018?

\section{KAJIAN LITERATUR}

\section{II.1. Teori pengaruh Current Ratio terhadap Return On Assets}

Menurut pengaruh Current Kodrat (2010:236), current ratio yang rendah menunjukkan risiko likuiditas yang tinggi. Sebaliknya current ratio yang tinggi menunjukkan adanya kelebihan aktiva lancar yang akan mempunyai pengaruh yang tidak baik terhadap profitabilitas perusahaan.

\section{I1.2 Teori pengaruh Debt To Equity Ratio terhadap Return On Assets}

Menurut Kasmir (2012:152) "apabila perusahaan ternyata memiliki rasio solvabilitas yang tinggi, hal ini akan berdampak timbulnya risiko kerugian lebih besar, tetapi juga ada kesempatan mendapat laba juga besar. Sebaliknya apabila perusahaan memiliki rasio solvabilitas lebih rendah tentu mempunyai risiko kerugian lebih kecil pula, terutama pada saat perekonomian menurun. Dampak ini juga mengakibatkan rendahnya tingkat hasil pengembalian (return) pada saat perekonomian tinggi”

\section{II.3 Teori pengaruh Inventory Turn Over terhadap Return On Assets}

Menurut Saniman (2007), semakin tinggi nilai inventory turn over yang diperoleh, semakin efisien perusahaan yang nilai perputaran persediaanya makin tinggi berarti makin efisien dalam kaitannya dengan pengendalian biaya, efisien dalam pengendalian biaya bagi perusahaan akan berdampak pada peningkatan perolehan laba. 


\section{II.4 Kerangka Konseptual}

Kerangka konseptual yang current ratio, debt to equity ratio, dan inventory turn over sebagai variabel independent dan variabel return on assets sebagai variabel dependen.

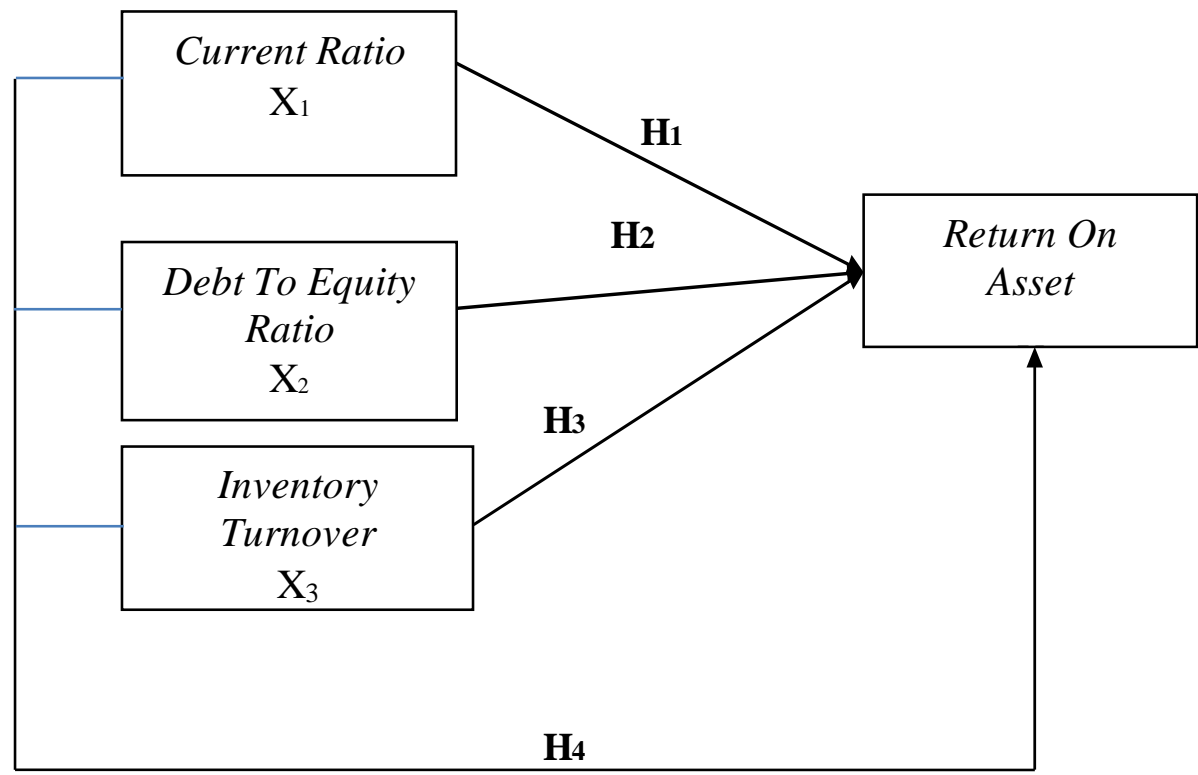

\section{Hipotensis Penelitian}

Menurut Sugiyono (2016:64), Hipotensis merupakan jawaban sementara terhadap rumusan masalah penelitian. Berdasarkan kerangka konseptual di atas, maka hipotensis dalam penelitian ini adalah :

H1 : Current Ratio berpengaruh secara parsial terhadap Return On Asset pada perusahaan sektor property dan real estate yang terdaftar di Bursa Efek Indonesia pada tahun 2014-2018.

H2: Debt to Equity Ratio berpengaruh secara parsial terhadap Return On Asset pada perusahaan sektor property dan real estate yang terdaftar di Bursa Efek Indonesia pada tahun 2014-2018.

H3: Inventory Turnover berpengaruh secara persial terhadap Return On Asset pada perusahaan property dan real estate di Bursa Efek Indonesia tahun 2014-2018.

H4 : Current Ratio, Debt to Equity Ratio, Inventory Turnover berpengaruh secara simultan terhadap Return On Asset pada perusahaan sektor property dan real estate yang terdaftar di Bursa Efek Indonesia tahun 2014-2018.

\section{METODE}

\section{III.1 Tempat dan Waktu Penelitian}

Tempat penelitian ini dilakukan pada perusahaan property dan real estate yang terdaftar di BEI tahun 2014-2018 melalui media browsing pada situs www.idx.co.id waktu penelitian direncanakan pada Januari 2019 hingga bulan Juli 2019. 


\section{III.2 Populasi dan Sampel \\ III.2.1Populasi}

Menurut Sugiyono (2016:80), populasi ialah wilayah generalisasi terdiri atas: obyek/subyek yang memiliki karakteristik dan kualitas tertentu yang telah ditetapkan peneliti untuk dapat dipelajari sehingga hasil penelitian dapat ditarik kesimpulannya. Populasi yang dipakai dalam penelitian ini adalah seluruh perusahaan property dan real estate yang terdaftar di BEI pada tahun 2014-2018 sebanyak 48 perusahaan.

\section{III.2.2Sampel}

Menurut Riduwan (2009:56), sampel ialah sebagian dari populasi yang memiliki ciri-ciri atau kondisi tertentu untuk diteliti. Teknik pengambilan sampel yang digunakan dalam penelitian adalah teknik purpose sampling. berikut :

Kriteria penentuan sampel dalam perusahaan dalam penelitian ini adalah sebagai

1. Perusahaan yang terdaftar dalam sektor Property dan real Estate di Bursa Efek Indonesia selama periode penelitian tahun 2014-2018.

2. Perusahaan yang melaporkan laporan keuangan perusahaan selama periode penelitian tahun 2014-2018

3. Perusahaan yang menghasilkan laba positif selama periode penelitian tahun 20142018.

Proses penyeleksian sampel secara garis besar dalam penelitian ini, dapat dilihat pada tabel berikut :

Tabel 2 Kriteria Pengambilan Sampel

\begin{tabular}{|c|l|c|}
\hline NO & \multicolumn{1}{|c|}{ KETERANGAN } & JUMLAH \\
\hline 1. & $\begin{array}{l}\text { Perusahaan sektor property dan real estate yang terdaftar di } \\
\text { Bursa Efek Indonesia periode 2014-2018 }\end{array}$ & 48 \\
\hline 2. & $\begin{array}{l}\text { Perusahaan sektor property dan real estate yang terdaftar di } \\
\text { Bursa Efek Indonesia yang tidak memiliki laporan keuangan } \\
\text { secara lengkap tahun 2014-2018 }\end{array}$ & (8) \\
\hline 3. & $\begin{array}{l}\text { Perusahaan sektor property dan real estate yang tidak } \\
\text { memperoleh laba selama periode 2014-2018 }\end{array}$ & (13) \\
\hline \multicolumn{1}{|c|}{ Jumlah Sampel Penelitian } & 27 \\
\hline
\end{tabular}

Berdasarkan penarikan sampel maka diperoleh 27 perusahaan dengan menggunakan data runtun waktu (time series) tahun 2014-2018 sehingga diperoleh sampel data sebanyak 135 diperoleh dari 27 perusahaan dikali 5 tahun.

\section{III.3 Uji Asumsi Klasik}

Uji asumsi klasik adalah bagian dari salah satu cara yang penting yang digunakan bagaimana mengetahui hasil estimasi regresi yang dilakukan benar-benar bebas dari adanya gejala- gejala multikolonieritas, heteroskedastisitas, dan autokorelasi. 


\section{III.3.1 Uji Normalitas}

Menurut Ghozali (2016:154), uji normalitas memiliki tujuan untuk menguji apakah variabel pengganggu, residual, atau model regresi memiliki distribusi normal. Seperti yang diketahui bahwa uji f dan $\mathrm{t}$ berasumsi bahwa nilai residual mengikuti distribusi normal.

\section{III.3.2 Uji Multikolinearitas}

Menurut Ghozali (2016:103), uji multikolinearitas memiliki tujuan untuk menguji apakah pada model regresi terdapat adanya korelasi antar variabel bebas. Model regresi yang baik harusnya tidak terjadi korelasi antara variabel independen saling berkorelasi, maka variabel-variabel ini tidak orogonal.

\section{III.3.3 Uji Autokorelasi}

Menurut Ghozali (2016 :107), uji Autokorelasi memiliki tujuan untuk menguji adanya model regresi linear terdapat korelasi antar kesalahan pengganggu pada periode $\mathrm{T}$ dengan kesalahan pada periode $\mathrm{T}-1$.

\section{III.3.4 Uji Heteroskedastisitas}

Menurut Ghozali (2016:134), uji heteroskedastisitas mmiliki tujuan untuk menguji apakah terdapat model regresi yang adanya ketidaksamaan variance dari residual suatu penelitian.kepengamatan yang lain. Suatu model regresi yang baik adalah tidak terjadi heteroskedastitsitas.

\section{III.4 Model Analisis Data Penelitian \\ III.4.1 Uji Persamaan Regresi}

Menurut Ghozali (2016:93), model regresi berganda dipakai untuk menegtahui adanya nya pengaruh dan hubungan variabel independen yang jumlahnya dua atau lebih $(\mathrm{X} 1, \mathrm{X} 2, \mathrm{X} 3)$ pada varibel dependen (Y). Pengujian hipotesis yang dipakai dalam pengamatan ini adalah analisis regresi linear berganda.

\section{III.4.2 Koefisien Determinasi hipotesis}

Menurut Ghozali (2013:171) koefisien determinasi (R2) dipakai pada menguji goodnessfit dari model regresi. Koefisien Determinasi adalah untuk mengukur seberapa jauh kemampuan model dalam menerangkan variasi variabel dependen.

\section{III.4.3 Pengujian Hipotesis secara Simultan (Uji F)}

Menurut Ghozali (2016:96), uji F menguji joint hipotesa bahwa b1, b2 dan b3 secara simultan sama dengan nol. Uji ini digunakan untuk membandingkan Fhitung dengan Ftabel dengan ketentuan sebagai berikut : $\mathrm{H} 0$ diterima dan Ha ditolak jika Fhitung $\leq$ Ftabel untuk $\alpha=$ $5 \%$ Ha diterima dan H0 ditolak jika Fhitung > Ftabel untuk $\alpha=5 \%$

\section{III.4.4 Pengujian Hipotesis secara Parsial (Uji t)}

Menurut Ghozali (2016:97), pengujian T-test dipakai untuk melihat seberapa jauh pengaruh satu variabel independen secara individual dalam menerangkan variasi variabel dependen. Uji ini digunakan untuk membandingkanThitung dengan Ttabel dengan ketentuan sebagai berikut : H0 diterima dan Ha ditolak jika -Ttabel $\leq$ Thitung $\leq$ Ttabel untuk $\alpha=5 \%$ Ha 
diterima dan H0 ditolak jika -Thitung < -Ttabel atau Thitung > Ttabel untuk $\alpha=5 \%$

Kriteria pengujian hipotesis secara parsial adalah sebagai berikut:

$\mathrm{H} 0$ : bi = 0 (artinya variabel current ratio,debt to equity ratio dan inventory turn over tidak berpengaruh secara parsial terhadap return on asset pada perusahaan sektor property dan real estate yang terdaftar di bursa efek indonesia periode 2014-2018)

HA : bi $\neq 0$ (artinya variabel current ratio,debt to equity ratio dan inventory turn over berpengaruh secara parsial terhadap return on asset pada perusahaan sektor property and real estate yang terdaftar di bursa efek indonesia periode 2014-2018.

\section{HASIL PENELITIAN DAN PEMBAHASAN}

\section{IV.1 Gambaran Umum Perusahaan Sektor Property dan Real Estate di BEI}

Sektor property dan real estate merupakan salah satu perusahaan yang mencakup dari beberapa usaha seperti penjualan, pembelian, penyewaan berbagai macam bangunan tempat tinggal. Penelitian ini menguji pengaruh current ratio, debt to equity dan inventory turn over terhadap profitibilitas yang diukur menggunakan ROA. Sampel penelitian ialah perusahaan Property dan Real Estate yang terdaftar di Bursa Efek Indonesia pada tahun 2014-2018 yaitu 27 perusahaan yang dijadikan sampel.

\section{IV.2 Hasil Penelitian}

\section{IV.2.1 Statistik Deskriptif}

Pengujian statistik deskriptif dilakukan untuk memberikan penjelasan mengenai nilai minimum, nilai maksimum, nilai rata-rata, dan nilai standar deviasi dari masingmasing variabel. Pengukuran nilai rata-rata (mean) merupakan cara yang paling umum dilakukan untuk mengukur nilai sentral dari suatu distribusi data. Standar deviasi dilakukan untuk mengukur seberapa luas atau seberapa jauh penyimpangan data dari nilai rata-ratanya. Hasil penelitian statistik deskriptif dapat dilihat pada tabel berikut :

Tabel 3 Statistik Deskriptif

\begin{tabular}{|c|c|c|c|c|c|}
\hline \multicolumn{7}{|c|}{ Descriptive Statistics } \\
\hline & N & Minimum & Maximum & Mean & Std. Deviation \\
\hline ln_cr & 135 & -.93 & 2.55 & .7138 & .72398 \\
\hline ln_der & 135 & -3.14 & 1.33 & -.5649 & .82774 \\
\hline ln_ito & 135 & -3.31 & 6.02 & .1831 & 2.06301 \\
\hline ln_roa & 135 & -8.09 & -.40 & -3.3195 & 1.31265 \\
\hline Valid N (listwise) & 135 & & & & \\
\hline
\end{tabular}

Dari hasil statistik deskriptif pada tabel 3 diatas, dapat dijelaskaan bahwa :

1. Variabel Current Ratio (X1) mempunyai sampel sebanyak 135, dengan nilai minimum -0,93 dan nilai maksimum 2,55 sedangkan nilai rata-rata 0,7138 dengan nilai standar deviasi 0,72398 .

2. Variabel Debt To Equity (X2) mempunyai sampel sebanyak 135, dengan nilai minimum $-3,14$ dan nilai maksimum 1,33 sedangkan nilai rata-rata $-0,5649$ dengan nilai standar deviasi 0,82774 . 
3. Variabel Inventory Turn Over (X3) mempunyai sampel sebanyak 135, dengan nilai minimum -3,31 dan nilai maksimum 6,02 sedangkan nilai rata-rata 0,1831 dengan nilai standar deviasi 2,06301.

4. Variabel Return On Asset (Y) mempunyai sampel sebanyak 135, dengan nilai minimum -8,09 dan nilai maksimum -0,40 sedangkan nilai rata-rata -3,3195 dengan nilai standar deviasi 1,31265 .

\section{IV.3 Uji Asumsi Klasik \\ IV.3.1 Uji Normalitas}

Ada dua cara untuk melihat apakah residual berdistribusi normal atau tidak, yaitu dengan analisis grafik dan uji statistik.

1. Analisis grafik, dengan melihat grafik histogram yang membandingkan antara data observasi dengan distribusi yang mendeteksi distribusi normal dan normal probabylity plot yang membandingkan distribusi kumulatif dari distribusi normal. Sebuah data dinyatakan berdistribusi normal apabila pola datanya tidak melenceng ke kiri atau ke kanan, melainkan menyebar di sekitar garis diagonal. Berikut uji analisis grafik histogram dan grafik normal probability plot sesudah transformasi.

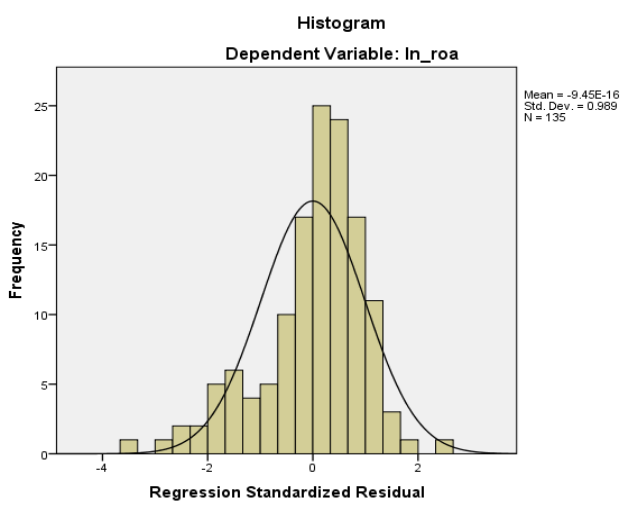

\section{Gambar 1 Uji Normalitas Grafik Histogram}

Sumber : Data Output SPSS, 2020

Dapat dilihat pada gambar 1 diatas bahwa plot grafik histogram menunjukkan pola distribusi yang berbentuk seperti gunung tanpa melenceng ke kiri atau ke kanan dan berdistribusi normal.

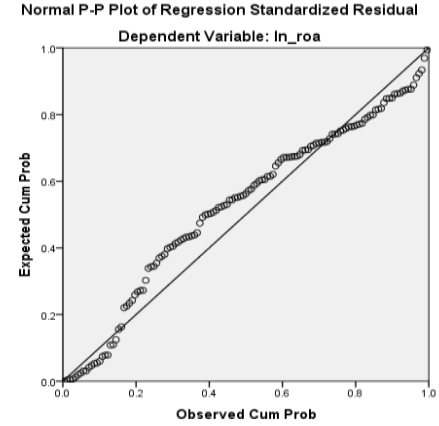

Gambar 2 Uji Normalitas Grafik Normal P-P Plot Sumber : Data Output SPSS, 2020

Pada gambar 2 dapat dilihat grafik normal p-plot menunjukkan gambaran pola data yang baik, dimana data menyebar disekitar garis diagonal, hal ini menunjukkan pola distribusi normal dan memenuhi asumsi normalitas. 
2. Analisis Statistik

Dalam analisis statistik, uji statistik yang dapat dilakukan untuk menguji normalitas residual adalah uji non-parametrik Kolmogrov-Smirnov (K-S). Dalam uji ini, pedoman yang dipakai dalam pengambilan keputusan adalah, jika nilai signifikan > 0,05 maka distribusi normal, jika nilai signifikan $<0,05$ maka distribusi tidak normal. Berikut uji kolmogrov-smirnov sesudah transformasi

Tabel 4 Uji Normalitas One-Sample Kolmogrov-Smirnov Test

\begin{tabular}{|c|c|c|}
\hline \multicolumn{3}{|c|}{ One-Sample Kolmogorov-Smirnov Test } \\
\hline & & $\begin{array}{l}\text { Unstandardized } \\
\text { Residual }\end{array}$ \\
\hline $\mathrm{N}$ & & 135 \\
\hline \multirow{3}{*}{ Normal Parameters ${ }^{\mathrm{a}, \mathrm{b}}$} & Mean & $0 \mathrm{E}-7$ \\
\hline & Std. Deviation & 1.24634975 \\
\hline & Absolute & .115 \\
\hline \multirow[t]{2}{*}{ Most Extreme Differences } & Positive & .077 \\
\hline & Negative & -.115 \\
\hline Kolmogorov-Smirnov Z & & 1.334 \\
\hline Asymp. Sig. (2-tailed) & & .057 \\
\hline
\end{tabular}

a. Test distribution is Normal.

b. Calculated from data.

Berdasarkan hasil kolmogrov-smirnov adalah sebesar 1,334 dengan nilai signifikan atau Asymp. Sig (2-failed) sebesar 0,057 hasil tersebut lebih besar daripada 0,05 yang artinya bahwa data berdistribusi secara normal.

\section{V.3.2 Uji Multikolinearitas}

Model regresi yang baik seharusnya tidak terjadi korelasi antara variabel independen. Pengujian multikolinearitas dapat dilakukan dengan melihat Variabel Inflation Factor (VIF) antar variabel independen. bila nilai tolerance $>0.1$ dan nilai VIF $<10$ maka tidak terjadi multikoliniearitas. Berikut ujji multikolinearitas sesudah transformasi.

Tabel 5 Multikolinearitas

\begin{tabular}{|c|c|c|c|c|c|c|c|}
\hline \multirow[t]{2}{*}{ Model } & \multicolumn{2}{|c|}{$\begin{array}{l}\text { Unstandardized } \\
\text { Coefficients }\end{array}$} & \multirow{2}{*}{$\begin{array}{c}\text { Standardized } \\
\text { Coefficients } \\
\text { Beta }\end{array}$} & \multirow[t]{2}{*}{$\mathrm{t}$} & \multirow[t]{2}{*}{ Sig. } & \multicolumn{2}{|c|}{ Collinearity Statistics } \\
\hline & $\mathrm{B}$ & Std. Error & & & & Tolerance & VIF \\
\hline $\begin{array}{l}\text { (Const } \\
\text { ant) }\end{array}$ & -3.464 & .164 & & -21.111 & .000 & & \\
\hline In_cr & .414 & .169 & .228 & 2.453 & .015 & .793 & 1.261 \\
\hline In_der & .313 & .148 & .198 & 2.117 & .036 & .790 & 1.265 \\
\hline In_ito & .140 & .056 & .220 & 2.486 & .014 & .876 & 1.142 \\
\hline
\end{tabular}

a. Dependent Variable:In_roa 
Berdasarkan tabel 5 diatas dapat dilihat bahwa hasil dari uji multikolinearitas adalah sebagai berikut :

1. Variabel Current Ratio (CR) mempunyai nilai tolerance sebesar 0,793>0,1 dan nilai VIF sebesar $1,261<10$

2. Variabel Debt to Equity (DER) mempunyai nilai tolerance sebesar 0,790>0,1 dan nilai VIF sebesar $1,265<10$

3. Variabel Inventory Turn Over (ITO) mempunyai nilai tolerance sebesar 0,876>0,1 dan nilai VIF sebesat $1,142<10$

Dari hasil diatas dapat disimpulkan bahwa tidak ada variabel bebas yang memiliki nilai tolerance lebih kecil dari 0,1 dan tidak ada yang memiliki nilai VIF lebih besar dari 10. Maka hasil tersebut menggambarkan tidak ada gejala multikolinearitas antar variabel independen.

\section{IV.3.3 Uji Autokorelasi}

Uji autokorelasai memiliki tujuan untuk menguji apakah dalam model regresi linear ada korelasi antara kesalahan penganggu pada periode t-1 (sebelumnya). Model regresi yang baik adalah bebas dari autokorelasi. Untuk menguji autokorelasi digunakan uji Durbin Watson. Berikut hasil pengujian autokorelasi sesudah transformasi.

Tabel 6 Autokorelasi

Model Summary ${ }^{b}$

\begin{tabular}{|l|r|r|r|r|r|}
\hline Model & $\mathrm{R}$ & $\mathrm{R}$ Square & $\begin{array}{c}\text { Adjusted R } \\
\text { Square }\end{array}$ & $\begin{array}{c}\text { Std. Error of the } \\
\text { Estimate }\end{array}$ & Durbin-Watson \\
\hline 1 & $.314^{\mathrm{a}}$ & .098 & .078 & 1.26054 & 1.827 \\
\hline
\end{tabular}

a. Predictors: (Constant), In_ito, In_cr, In_der

b. Dependent Variable:In_roa

Berdasarkan tabel 6 dapat dilihat nilai Durbin-Watson (DW) sebesar 1,827. Nilai ini dibandingkan dengan nilai tabel jumlah variabel independen $3(k=3)$ dan $n$ jumlah observasi $(\mathrm{n}=135)$. Maka dari tabel DW diperoleh nilai dl 1,6738 dan nilai du 1.7645. Dengan melihat kriteria pengambilan keputusan pada Durbin-Watson maka nilai du < DW < 4-du $(1,7645<$ $1,827<2,2355)$. Maka dapat disimpulkan kesimpulan bahwa tidak terjadi autokorealasi dalam penelitian ini.

\section{IV.3.4 Uji Heteroskedastisitas}

Uji heterokedastisitas memiliki tujuan untuk menguji apakah dalam model regresi terjadi ketidaksamaan varian dari residual satu pengamatan ke pengamatan yang lain. Uji heteroskedasitas dapat dilihat dari uji grafik scatterplot dan uji glejser. Berikut grafik scatterplot sesudah transformasi.

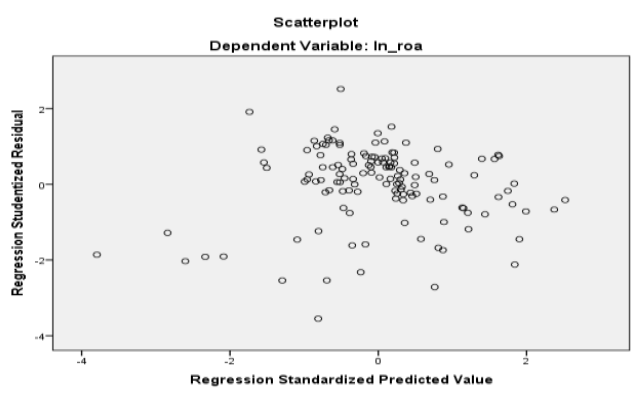

Gambar 3 Grafik Scaterplot

Sumber : Data Output SPSS,2020 
Berdasarkan gambar 3 diatas terlihat titik-titik menyebar secara acak serta tersebar secara baik diatas maupun dibawah angak 0 pada sumbu Y. Sehingga dapat disimpulkan bahwa tidak terjadi heteroskedastisitas. Sedangkan uji statistik yang dilakukan dengan uji Glejser dapat dilihat pada tabel berikut :

Tabel 7 Uji Glejser

\begin{tabular}{|c|c|c|c|c|c|c|}
\hline \multicolumn{7}{|c|}{ Coefficients $^{\mathbf{a}}$} \\
\hline & \multirow{2}{*}{ Model } & \multicolumn{2}{|c|}{ Unstandardized Coefficients } & \multirow{2}{*}{$\begin{array}{c}\text { Standardized } \\
\text { Coefficients }\end{array}$} & \multirow{2}{*}{$\mathrm{T}$} & \multirow{2}{*}{ Sig. } \\
\hline & & B & $\begin{array}{l}\text { Std. } \\
\text { Error }\end{array}$ & & & \\
\hline \multirow{4}{*}{1} & (Constant) & .044 & .007 & & 5.865 & .000 \\
\hline & ln_cr & -.010 & .008 & -.123 & -1.259 & .210 \\
\hline & ln_der & -.007 & .007 & -.106 & -1.084 & .280 \\
\hline & ln_ito & $2.026 \mathrm{E}-005$ & .003 & .001 & .008 & .994 \\
\hline
\end{tabular}

a. Dependent Variable: ln_RES2

Berdasarkan tabel 7 terlihat nilai signifikan Current Ratio adalah 0,210>0,05, nilai signifikan Debt to Equity Ratio adalah 0,280 > 0,05, dan nilai signifikan Inventory Turn Over adalah 0,994 > 0,05. Sehingga dapat disimpulkan bahwa Current Ratio, Debt to Equity Ratio, Inventory Turn Over tidak terjadi gejala heteroskedastisitas.

\section{IV.4 Hasil Analisis Data Penelitian}

\section{IV.4.1 Model Analisis Data}

Model penelitian yang dibuat dalam penelitian ini adalah menggunakan analisis regresi linear berganda bertujuan untuk mengetahui besarnya pengaruh Current Ratiro, Debt to Equity Ratio, dan Inventory Turn Over terhadap Return On Asset. Berikut hasil uji analisi regresi linier berganda sesudah transformasi.

Tabel 8 Analisis Regresi Linier Berganda

\begin{tabular}{|c|c|c|c|c|c|c|}
\hline \multirow{2}{*}{\multicolumn{2}{|c|}{ Model }} & \multicolumn{2}{|c|}{ Unstandardized Coefficients } & \multirow{2}{*}{$\begin{array}{c}\begin{array}{c}\text { Standardized } \\
\text { Coefficients }\end{array} \\
\text { Beta }\end{array}$} & \multirow[t]{2}{*}{$\mathrm{T}$} & \multirow[t]{2}{*}{ Sig. } \\
\hline & & B & Std. Error & & & \\
\hline \multirow{4}{*}{1} & (Constant) & -3.464 & .164 & & -21.111 & .000 \\
\hline & ln_cr & .414 & .169 & .228 & 2.453 & .015 \\
\hline & ln_der & .313 & .148 & .198 & 2.117 & .036 \\
\hline & ln_ito & .140 & .056 & .220 & 2.486 & .014 \\
\hline
\end{tabular}

a. Dependent Variable: In_roa

Berdasarkan tabel 8 diatas maka diperoleh persamaan regresi linear berganda sebagai berikut :

$$
\text { LN_ROA }=-3,464+0,414 \text { LN_CR + 0,313LN_DER + 0,140LN_ITO }
$$

Dari persamaan regresi linier berganda diatas dapat diartikan sebagai berikut :

1. nilai konstanta sebesar $-3,464$ menunjukkan apabila nilai CR,DER, dan ITO dianggap konstan, maka nilai ROA pada perusahaan sektor property dan real estate sebesar 3,646 .

2. Nilai koefisien CR sebesar 0,414 menunjukkan bahwa setiap peningkatan CR satu kali akan diikuti peningkatan ROA sebesar 0,414 dengan asumsi semua variabel independen dianggap nol. 
3. Nilai koefisien DER sebesar 0,313 menunjukkan bahwa setiap peningkatan DER satu kali akan diikuti peningkatan ROA sebesar 0,313 dengan sumsi semua variabel independen dianggap nol

4. Nilai koefisien ITO sebesar 0,140 menunjukkan bahwa setiap peningkatan ITO satu kali akan diikuti peningkatan ROA sebesar 0,140 dengan asumsi semua variabel independen dianggap nol.

\section{IV.4.2 Koefisien Determinasi $\left(\mathbf{R}^{\mathbf{2}}\right)$}

Koefisien Determinasi ialah untuk mengukur seberapa jauh kemampuan model dalam menerangkan variasi variabel dependen. Nilai koefisien determinasi adalah diantara nol dan satu. Nilai R2 yang kecil berarti kemampuan variabel-variabel independen dalam menjelaskan variasi variabel dependen terbatas. Nilai yang mendekati satu berarti variabel-variabel independen memberikan hampir semua informasi yang dibutuhkan untuk memprediksi variasi variabel dependen.

\begin{tabular}{|l|r|r|r|r|r|}
\multicolumn{7}{c|}{$\begin{array}{c}\text { Tabel 9 Koefisien Determinasi } \\
\text { Model Summary }\end{array}$} \\
\hline Model & $\mathrm{R}$ & R Square & $\begin{array}{c}\text { Adjusted R } \\
\text { Square }\end{array}$ & $\begin{array}{c}\text { Std. Error of the } \\
\text { Estimate }\end{array}$ & Durbin-Watson \\
\hline 1 & $.314^{\mathrm{a}}$ & .098 & .078 & 1.26054 & 1.827 \\
\hline
\end{tabular}

a. Predictors: (Constant), In_ito, In_cr, In_der

b. Dependent Variable: In_roa

Pada tabel 9 diatas, hasil analisa regresi dapat dilhat nilai $\mathrm{R}$ Square sebesar 0,098 menunjukkan bahwa korelasi atau keeratan hubungan CR,DER, dan ITO 9,8\%. Nilai Adjusted R Square sebesar 0,078 mengindikasikan bahwa variasi CR,DER,dan ITO menjelaskan variasi variabel terhadap ROA sebesar 7,8\% sedangkan sisanya 92,2\% dijelaskan oleh faktor-faktor lain diluar variabel yang belum diteliti.

\section{IV.4.3 Pengujian Hipotesis Secara Simultan ( uji F )}

Uji F pada dasarnya mengetahui apakah semua variabel independen yang dimasukkan kedalam model regresi mempunyai pengaruh secara bersama-sama terhadap variabel dependen. Kriteria pengujian uji $\mathrm{F}$ sebagai berikut :

a. jika $F_{\text {hitung }}$ lebih besar dari $F_{\text {tabel }}$ atau variabel independen lebih kecil dari tingkat signifikan (Sig < 0,05), maka model penelitian ini dapat digunakan atau signifikan.

b. Jika $F_{\text {hitung }}$ lebih besar dari $F_{\text {tabel }}$ atau variabel independen lebih besar dari tingkat signifikan $($ Sig $>0,05)$, maka model penelitian ini tidak dapat digunakan atau tidak signifikan.

Pada penelitian dilihat melalui jumlah sampel (n) adalah 135 dan jumlah variabel keseluruhan (k) adalah 4 maka diperoleh $\mathrm{df}_{1=} \mathrm{k}-1(4-1=3)$ dan $\mathrm{df}_{2=}(\mathrm{n}-\mathrm{k})(135-4=131)$. Dari hasil penelitian tersebut di dapatkan nilai $\mathrm{F}$ dan signifikan secara simultan adalah sebagai berikut:

Tabel 10 Uji F

\begin{tabular}{|c|c|c|c|c|c|c|}
\hline \multicolumn{7}{|c|}{ ANOVA $^{\mathbf{a}}$} \\
\hline & Model & Sum of Squares & $\mathrm{df}$ & Mean Square & $\mathrm{F}$ & Sig. \\
\hline \multirow{3}{*}{1} & Regression & 22.733 & 3 & 7.578 & 4.769 & $.003^{\mathrm{b}}$ \\
\hline & Residual & 208.154 & 131 & 1.589 & & \\
\hline & Total & 230.887 & 134 & & & \\
\hline
\end{tabular}

a. Dependent Variable: $\ln \_$roa

b. Predictors: (Constant), ln_ito, ln_cr, ln_der 
Berdasarkan tabel 10 diatas diketahui nilai signifikan untuk pengaruh CR,DER,dan ITO secara simultan terhadap ROA adalah sebesar 0,003 < 0,05 dan nilai $\mathrm{F}_{\text {hitung }}$ 4,769 > 2,67 maka dapat disimpulkan CR,DER, dan ITO secara simultan berpengaruh signifikan terhadap ROA.

\section{IV.4.4 Pengujian Hipotesis Secara Parsial (Uji t)}

Uji statistik t atau uji parsial dilakukan untuk mengetahui signifikasi pengaruh seberapa jauh variabel independen secara parsial atau sendiri-sendiri dalam menerangkan variabel dependen. Kriteria signifikan atau tidak signifikan hipotesis secara parsial sebagai berikut :

- Apabila variabel independen $<0,05$ maka variabel tersebut signifikan

- Apabila variabel independen >0,05 maka variabel tersebut tidak signifikan

Berikut hasil tabel dari uji $\mathrm{t}$ :

Tabel 11 Uji t

\begin{tabular}{|c|c|c|c|c|c|}
\hline \multicolumn{6}{|c|}{ Coefficients $^{\mathrm{a}}$} \\
\hline \multirow[t]{2}{*}{ Model } & \multicolumn{2}{|c|}{$\begin{array}{l}\text { Unstandardized } \\
\text { Coefficients }\end{array}$} & \multirow{2}{*}{$\begin{array}{c}\text { Standardized } \\
\text { Coefficients }\end{array}$} & \multirow[t]{2}{*}{$\mathrm{t}$} & \multirow[t]{2}{*}{ Sig. } \\
\hline & $\mathrm{B}$ & Std. Error & & & \\
\hline (Constant) & -3.464 & .164 & & -21.111 & .000 \\
\hline ln_cr & .414 & .169 & .228 & 2.453 & .015 \\
\hline ln_der & .313 & .148 & .198 & 2.117 & .036 \\
\hline ln_ito & .140 & .056 & .220 & 2.486 & .014 \\
\hline
\end{tabular}

a. Dependent Variable: 1 n_roa

Berdasarkan hasil dari tabel 11 setelah transformasi dapat disimpulkan sebagai berikut:

1. Variabel CR secara parsial memiliki thitung $>t_{\text {tabel }}$ sebesar 2,453>1,978 dengan nilai signifikan $0,015<0,05$ artinya bahwa dapat dinyatakan secara parsisl CR berpengaruh signifikan terhadap ROA.

2. Variabel DER secara parsial memiliki $t_{\text {hitung }}>t_{\text {tabel }}$ sebesar $2,117>1,978$ dengan nilai signifikan $0,036<0,05$ artinya bahwa dapat dinyatakan secara parsial DER berpengaruh signifikan terhadap ROA.

3. Variabel ITO secara parsial memilki $t_{\text {hitung }}>t_{\text {tabel }}$ sebesar 2,486 $>1,978$ dengan nilai signifikan 0,014 $<0,05$ artinya bahwa dapat dinyatakn secara parsial ITO berpengaruh signifikan terhadap ROA.

\section{IV.5 Pembahasan Hasil Penelitian}

\section{IV.5.1 Pengaruh Current Ratio Terhadap Return On Asset}

Berdasarkan hasil pengujian hipotesis menyatakan secara parsial variabel CR memiliki nilai $t_{\text {hitung }}>t_{\text {tabel }}(2,435>1,978)$ dengan nilai signifikan $0,015<0,05$. Hasil tersebut menunjukkan $\mathrm{h}_{1}$ diterima yang artinya secara parsial CR berpengaruh signifikan terhadap ROA.

Hasil penelitian ini sejalan dengan penelitian sebelumnya yang dilakukan oleh Indra Wijaya dan Nurlaila Isnani (2019) dengan judul "Pengaruh Efisiensi Modal Kerja, Likuditas (CR), dan Solvabilitas terhadap Profitabilitas (ROA) Perusahaan Farmasi" yang menyatakan bahwa secara parsial CR berpengaruh terhadap ROA. 


\section{IV.5.2 Pengaruh Debt To Equity Ration Terhadap Return On Asset}

Berdasarkan hasil pengujian hipotesis menyatakan secara parsial variabel DER memiliki nilai $t_{\text {hitung }}>t_{\text {tabel }}(2,117>1,978)$ dengan nilai signifikan $0,036<0,05$. Hasil tersebut menunjukkan bahwa $\mathrm{h}_{2}$ diterima yang artinya secara parsial DER berpengaruh signifikan terhadap ROA.

Hasil penelitian ini sejalan dengan penelitian sebelumnya yang dilakukan oleh Dede Solihin (2019) dengan judul "Pengaruh Current Ratio dan Debt To Equity Ratio Terhadap Return On Asset Pada PT Kalbe Farma,Tbk" yang menyatakan bahwa secara parsial DER berpengaruh terhadap ROA.

\section{IV.5.3 Pengaruh Inventory Turn Over Terhadap Return On Asset}

Berdasarkan hasil pengujian hipotesis menyatakan secara parsial vaariabel ITO memiliki nilai $t_{\text {hitung }}>t_{\text {tabel }}(2,486>1,978)$ dengan nilai signifikan $0,014<0,05$. Hasil tersebut menunjukkan bahwa $\mathrm{h}_{3}$ diterima yang artinya secara parsial ITO berpengaruh signifikan terhadap ROA.

Hasil penelitian ini sejalan dengan penelitian sebelumnya yang dilakukan oleh Lucya Dewi Wikardi dan Natalia Titik Wiyani (2017) dengan judul "Pengaruh Debt to Equity Ratio, Firm Size, Inventory Turnover, Assets Turnover dan Pertumbuhan Penjualan Terhadap Profitabilitas Pada Industri Makanan dan Minuman yang Terdaftar di BEI Periode 2011-2015" yang menyatakan bahwa secara parsial ITO berpengaruh terhadap ROA.

\section{KESIMPULAN}

Berdasarkan penejelasan dan hasil pembahasan bab sebelumnya, maka dapat ditarik beberapa kesimpulan sebagai berikut :

1. Secara parsial, variabel Current Ratio (CR) berpengaruh signifikan terhadap Return On Asset dengan tingkat signifikan 0,015 <0,05.

2. Secara parsial, variabel Debt to Equity Ratio (DER) berpengaruh signifikan terhadap Return On Asset dengan tingkat signifikan 0,036 < 0,05.

3. Secara parsial, variabel Inventory Turn Over (ITO) berpengaruh signifikan terhadap Return On Asset dengan tingakat signifikan 0,014<0,05.

4. Nilai signifikan CR,DER,dan ITO secara simultan terhadap ROA adalah sebelah $0,003<0,05$, sehingga dapat dismpulkan bahwa hipotesis $\mathrm{h}_{4}$ diterima yang berarti terdapat pengaruh CR,DER, dan ITO secara simultan terhadap ROA.

\section{REFRENSI}

Dede Solihin. 2019. Pengaruh Current Ratio dan Debt to Equity Ratio Terhadap Return On Asset Pada PT Kalbe Farma.

Ghojali, Imam. 2016. Aplikasi Analisis Multivariate Dengan Program IBM SPSS 23. Semarang: Badan Penerbit Universitas Dipenegoro.

Indra Wijaya, Nurlaila Isnani. 2019. Pengaruh Efisiensi Modal Kerja, Likuditas, dan Solvabilitas terhadap Profitabilitas Perusahaan Farmasi. 
Kasmir. Analisis Laporan Keuangan. Cetakan Kelima. Jakarta : PT Rajagrafindo Persada, 2012

Kodrat, David Sukardi \& Kurniawan Indonanjaya. 2010. Manajemen Investasi. Cetakan pertama. Yogyakarta: Graha Ilmu

Lucya Dewi Wikardi, Natalia Titik Wiyani. 2017. Pengaruh Debt to Equity Ratio, Firm Size, Inventory Turnover,Assets Turnover dan Pertumbuhan Penjualan Terhadap Profitabilitas Studi Kasus Pada Industri Makanan dan Minuman.

Riduwan. 2009. Belajar Mudah Penelitian Untuk Guru - Karyawan dan Peneliti Mudah. Bandung : Alfabeta.

Sugiyono Metode Penelitian Kuantitatif dan R\&D. Cetakan Ketujuh Belas. Bandung : Penerbit Alfabeta, 2016. 